\title{
SYTUACJA ESTETYCZNA W ŚWIECIE AGENCJI REKLAMOWYCH. CO SOCJOLOGIA REKLAMY MOŻE ZACZERPNĄĆ Z ESTETYKI I SOCJOLOGII SZTUKI?
}

\section{Wprowadzenie: sytuacja estetyczna w produkcji reklamowej}

W polskiej estetyce pojęcie „sytuacja estetyczna” rozwinęła Maria Gołaszewska, nadając bardziej szczegółowy sens terminowi, którym jako pierwszy posłużył się Roman Ingarden w wykładzie z 1960 roku [Ostrowicki 1996: 4]. Według Gołaszewskiej sytuacja estetyczna jest konstruktem teoretycznym „strukturującym w spójną całość elementy brane pod uwagę, gdy ujmujemy świat człowieka (rzeczywistość zhumanizowaną) w aspekcie wartości estetycznych, przyjmujemy wobec niego postawę estetyczną" [Gołaszewska 1984: 23]. Podstawowe składowe sytuacji estetycznej: odbiorca, twórca i dzieło - są podporządkowane wartościom estetycznym uznawanym przez człowieka. Dogłębna analiza filozoficzna pozwala wyróżnić znacznie więcej elementów sytuacji estetycznej. Poza wymienionymi mogą być to: założenia artystyczne, realizacja dzieła, zamiar artystyczny, przedmiot estetyczny, rozumienie dzieła sztuki, fascynacja estetyczna, proces twórczy, przeżycie estetyczne, osobowość twórcy i osobowość odbiorcy, fascynacja naturą, wrażliwość na jakość i wartość artystyczną [Gołaszewska 1970: 55]. Warto zwrócić uwagę na fakt, że w tradycji fenomenologicznej sytuacja estetyczna jest procesem, a nie ustalonym dla pewnej sytuacji zbiorem elementów wpływających na powstawanie i odbiór działa [por. Sosnowski 1999: 104]. Właściwym przedmiotem analizy powinny być więc nie elementy, a relacje pomiędzy nimi. Jest to oczywiście podejście zgodne z duchem socjologii Pierre’a Bourdieu, która koncentrowała się nie na elementach struktury społecznej, ale dynamice przemian pomiędzy nimi.

Większość prawidłowości związanych z procesem powstawania dzieła, zaobserwowanych przeze mnie podczas badań terenowych $\mathrm{w}$ polskich agencjach reklamowych, daje się w klarowny sposób przedstawić 
za pomocą uproszonego modelu sytuacji estetycznej (twórca, odbiorca, dzieło, wartość estetyczna). Największe znaczenie ma w tym przypadku fakt, że twórcy reklam opracowują swoje prace dzięki zinternalizowanym wartościom estetycznym, a także wyobrażeniom na temat odbiorców.

$\mathrm{Na}$ początku artykułu dokonuję porównania pozycji, jakie w swoich polach społecznych [por. Bourdieu 1993, Bourdieu 2005] zajmują artyści i twórcy reklam. Koncentruję się głównie na różnicach ekonomicznych i podobieństwie procesu twórczego. W dalszych częściach artykułu odpowiadam na dwa podstawowe pytania badawcze:

1. Jaką rolę odgrywają wartości estetyczne w życiu pracowników kreatywnych?

2. W jaki sposób starają się oni odkryć potrzeby odbiorców?

\section{Metodologia badania}

Prezentowane wyniki są częścią większego projektu, który dotyczył estetyki polskiej reklamy prasowej [Łuczaj 2016] ${ }^{1}$. Zastosowaną techniką badawczą był indywidualny wywiad pogłębiony, który pozwolił zebrać bogate dane na temat różnych problemów umieszczonych w scenariuszu wywiadu. Wszystkie rozmowy przeprowadziłem na przełomie 2014 i 2015 roku. Zostały one nagrane, a następnie przetranskrybowane, co w sumie dało ponad 830 stron znormalizowanego maszynopisu. Łącznie przeprowadziłem wywiady z 22 pracownikami polskich agencji reklamowych, którzy są bezpośrednio odpowiedzialni za przygotowanie reklam. Osoby te dobrano celowo, aby reprezentowały różne stanowiska (dyrektorzy kreatywni, copywriterzy, dyrektorzy artystyczni, inni członkowie zespołów kreatywnych) i posiadały różny staż pracy w branży reklamowej (kilka do kilkunastu lat, więcej w przypadku dyrektorów kreatywnych) ${ }^{2}$. Najmłodsza z rozmówczyń miała 24 lata, najstarszy rozmówca -43 lata $^{3}$.

1 Realizacja badań była możliwa dzięki grantowi badawczemu Narodowego Centrum Nauki nr 2012/07/N/HS6/00469.

2 W trosce o prywatność badanych nie podaję tu danych szczegółowych. Polska branża reklamowa jest stosunkowo mała i teoretycznie istnieje możliwość identyfikacji konkretnego dyrektora kreatywnego po stażu jego pracy.

3 W badaniu wzięło udział po 11 kobiet i mężczyzn, jednak płeć wydawała się nie wiązać z żadnym konkretnym poglądem lub ideą, które omawialiśmy. Połowa badanych studiowała na kierunku artystycznym, połowa - nie. 


\section{Twórca reklamy i artysta - dwie różnice ekonomiczne}

Dwie podstawowe różnice pomiędzy artystą a twórcą reklamy mają charakter ekonomiczny. Ci drudzy mają zwykle bardzo konkretnie wyznaczony zakres obowiązków i katalog wymagań (np. staż pracy w reklamie, doświadczenie z konkretnymi mediami, a także, o czym przekonamy się dalej, dość niejednoznaczne oczekiwania w zakresie "gustu”). W zamian za to osiągają stabilne, przewidywalne i relatywnie wysokie zarobki. $\mathrm{W}$ przeciwieństwie do tego, profesja twórcy $\mathrm{w}$ polu artystycznym jest jedną z najmniej ustrukturyzowanych. Dlatego pojawiają się tam osoby o bardzo różnych kwalifikacjach, mające zróżnicowane szanse na odniesienie sukcesu. Zajęcie artystyczne, zdaniem Bourdieu, prawie zawsze wymaga podjęcia innej pracy, o bardziej zarobkowym charakterze [Bourdieu 1993: 43]. Oznacza to, jak pisze Tomasz Warczok, że pisarze (inaczej niż badani przeze mnie kreatywni) „działają zwykle i socjalizowani są w co najmniej dwóch różnych światach" [Warczok 2013: 33]. Zaobserwował to też Bernard Lahire na przykładzie badanych przez siebie pisarzy [Lahire 2006, por. Warczok 2013] ${ }^{4}$. Ich położenie ekonomiczne stanowi zupełne przeciwieństwo sytuacji znanej ze świata reklamy, gdzie pracownik związany jest zwykle z jedną agencją, ponieważ obowiązują zapisy o zakazie konkurencji. W Polsce, jak wynika z moich badań, nawet relatywnie młode osoby mogą liczyć na wysokie wynagrodzenia, sięgające dziecięciu tysięcy złotych miesięcznie netto. Z takimi zarobkami wiąże się jednak konieczność rezygnacji $\mathrm{z}$ autonomii przypisywanej tradycyjnie wolnym zawodom. Praca w agencji reklamowej przypomina typową pracę biurową. Godziny są (mniej lub bardziej sztywno) ustalone.

Różnica położenia ekonomicznego artystów i twórców reklam jest więc wyraźna. Ceną za wyższe zarobki jest zgoda na rezygnację z możliwości samodzielnego planowania swojego czasu, nie wspominając nawet o zadaniach, które trzeba wykonać, a które artysta „ze świata sztuki”, w przeciwieństwie do artysty „na etacie”, ustala sobie sam. To w opinii kreatywnych duża

4 W kontekście przywoływanej przeze mnie powyżej tezy Bourdieu o konieczności łączenia pracy zarobkowej z zajęciem artystycznym, wskazywane przez Tomasza Warczoka prekursorstwo Lahire’a w zakresie pokazania niejednorodności habitusu jest więc wątpliwe. W podobny sposób przesadzona jest krytyka Jean-Claude’a Kaufmana [2004]. Teoria Bourdieu bez wątpienia kładzie duży nacisk na spójność habitusu, jednak krzywdzące dla autora Dystynkcji jest twierdzenie, że bronił on homogenicznego habitusu, nie dopuszczając wyjątków. Z mojej perspektywy Lahire i Kaufman opisują aspekt, który w teorii Bourdieu nie został wystarczająco jasno naświetlony, ale niewątpliwie jest tam obecny. 
strata i właśnie z tego względu część badanych przeze mnie osób planuje albo powrócić do zawodu artystycznego lub też zająć się zupełnie czymś innym (np. praca w jednym $\mathrm{z}$ afrykańskich parków narodowych, hodowla marchewek ekologicznych). Strategię przetrwania podobną do tej zaobserwowanej przeze mnie w polskich agencjach reklamowych wskazali Pierre Bourdieu i Jean-Claude Passeron [1979] w swojej pierwszej wspólnej książce poświęconej nierównościom edukacyjnym, Les Héritiers (Spadkobiercy). Osoby pracujące we francuskiej branży reklamowej - zauważają autorzy często uważały się na przykład za artystów malarzy, którzy tylko „tymczasowo" wykonują inną pracę. W tym sensie ich narracja życiowa podobna jest do narracji współczesnych osób, określanych jako pokolenie „ukośników” (slashies), będących na przykład barmanami/aktorami, sekretarkami/analityczkami biznesowymi [Tracewicz 2017]. Nagły zastrzyk gotówki mógłby spowodować, uważają Bourdieu i Passeron [1979: 92], że takie rozdwojone osoby wróciłyby do swojego „prawdziwego” zawodu i odzyskały niezależność. Na razie jednak podlegają oni kryteriom oceny charakterystycznym dla pola produkcji reklamy [por. Łuczaj 2017]. Pod tym względem, odwołując się do starej dychotomii [por. Horowitz 1975, Becker 1982, Gronow 1997, Łuczaj 2016], kreatywni są więc raczej rzemieślnikami niż artystami. Dlaczego więc socjologia sztuki może okazać się przydatna do analizy ich pracy? Spoiwem może być proces twórczy [por. Golka 1994].

\section{Gry symboliczne ukryte za prostą formą}

Analizę procesu twórczego w agencjach reklamowych warto rozpocząć od powrotu do kategorii rzemieślnika, którą wnikliwie opisał Richard Sennett [2008]. Główną cechą pracy rzemieślnika jest konieczność długotrwałego skupienia nad każdym szczegółem przedmiotu, który wytwarza. W pracy rzemieślnika obserwujemy stały, mierzalny postęp. Proces twórczy może być również bardzo rozciągnięty w czasie, lecz jego efekt końcowy czasami nie nosi śladów długotrwałego wysiłku (który niewątpliwie jest udziałem twórców rozważających różne idee i możliwości). Ilość pracy, którą trzeba włożyć w wykonanie danego przedmiotu jest tymczasem jednym z głównych wyznaczników jego wartości, którym posługują się członkowie klas ludowych [Szlendak 2011, por. Wypijewski 1997: 35] - osoby mniej zasobne w kapitał ekonomiczny, kulturowy i symboliczny. Za złożony rezultat, w myśl przywoływanej zasady estetyki ludowej, trudno uznać takie ikoniczne prace, jak 4'33"Johna Cage'a czy Krowa Andy'ego Warhola, co nie 
umniejsza krytycznej lub refleksyjnej wartości tych dzieł, jaka się za nimi kryje [por. Gołaszewska 1984]. Nie trzeba zresztą sięgać po ikony. Jeżeli weźmiemy pod uwagę tylko letnią ofertę warszawskiej Zachęty z 2016 roku, okaże się, że wiele skłaniających do refleksji prac ma nieskomplikowaną formę. Stare samochody marki Mazda ustawione tam przez Rafała Bujnowskiego w ramach wystawy Maj 2066 czy buty uchodźców zbierane na Lampedusie i następie ustawione przez Sisleja Xhafę ${ }^{5} \mathrm{w}$ formie łodzi to instalacje, technicznie rzecz biorąc, niezbyt skomplikowane. Nie oznacza to, że u ich podstaw nie tkwi głęboka refleksja lub że refleksja nie towarzyszy odbiorcom wystawy. Nie jest ona jednak widoczna na pierwszy rzut oka. Mistrzostwo tych prac nie tkwi w samym efekcie oglądanym przez widzów, ale $\mathrm{w}$ refleksji, która doprowadziła do umieszczenia tych przedmiotów w tym miejscu. Dekodowanie tego typu prac, podobnie jak prac Wielkiej Awangardy [Gołaszewska 1984], stanowi jednak wysiłek intelektualny, który wykracza poza czysto zmysłową przyjemność.

Niektóre czołowe osiągnięcia świata reklamy również mogą wydać się proste. Hasło marki Nike „Just do it” nie wygląda na efekt długich zabiegów i prac rzesz ekspertów. A jednak jego powstanie najprawdopodobniej wymagało długich godzin, narad, spotkań. O sile hasła stanowi dobre rozpoznanie kontekstu sytuacyjnego. Nike, jako marka przeznaczona dla osób ćwiczących fizycznie, podkreśla możliwość przełamywania granic [Holt, Cameron 2010]. Najbardziej genialne, a więc obecne w świadomości zbiorowej, hasła reklamowe takie jak „The Freshmaker” (Mentos), „Das Auto” (Volkswagen) czy „Ojciec prać” (Pollena) to tylko proste zestawienia słów. Prawdziwa głębia znajduje się jednak w tym, co ukryte. Odpowiednio ukształtowany przekaz umożliwia odbiorcy zdekodowanie przekazu, który stoi za hasłem. Czasami jest to łatwiejsze, tak jak w przypadku odwołania do polskiej mitologii narodowej („Ojciec prać”) lub jakości kojarzonej z konkretnym krajem („Das Auto”). Niektóre reklamy wykorzystują jednak wyłomy w kulturowej ortodoksji, prezentując przekaz odzwierciedlający ukryte pragnienia konsumentów [Holt i Cameron 2010]. Tak było na przykład z hasłem "Just do it", które - osadzone na tle innych elementów komunikacji marki (wykorzystanie czarnoskórych sportowców) - można interpretować jako sprzeciw wobec rasizmu, seksizmu i globalnego ubóstwa. 


\section{Estetyka w codziennym życiu twórców reklam}

W pracy poświęconej polu produkcji kulturowej Pierre Bourdieu [1993: 66] pisze, że bycie artystą może być bardziej pociągające niż sama sztuka. Artyści, podobnie jak intelektualiści, zawsze dążą do stylu bycia bliżej "młodych” niż „starych” - ubierają się nieformalnie i tak też starają się stylizować własne ciało [1993: 105]. Jeżeli za Richardem Floridą [2010] uznać, że zarówno artyści, intelektualiści, jak i pracownicy przemysłów kreatywnych należą do jednej „klasy”, zrozumiałe może wydać się, dlaczego wybory estetyczne podejmowane przez nich w życiu codziennym są podobne. Za spoiwo tej klasy można uznać estetyzm, który rozumiem tu jako przywiązywanie wagi do rzeczy, którymi człowiek się otacza. Analizę tej specyficznej estetyki codzienności najlepiej rozpocząć od sposobu ubrania. Niepisane wymagania dotyczące wyglądu kreatywnych dobrze widać w następujących cytatach:

R21: Nawet oczekiwanie jest takie, że jaki klient spotyka się z kreacją, to oczekuje jakiegoś takiego wariactwa. I taki wariat, który tam jest, to jest...

R22: Tak dziwnie ubrany.

R21: No właśnie taki artysta.

R22: Spóźni się, zapomni czegoś.

R21: Taki właśnie artysta jest bardzo pożądany [W21] $]^{6}$.

Jak powiedziałam jednemu koledze, jak zaczynałam pracę w [nazwa agencji - K.Ł.], że będę copywriterem, to mi powiedział idealnie wyglądasz na copywritera, no może coś takiego jest [W16] $]^{7}$.

Więc to jest różnie odbierane, ale gdzieś tam chyba wymaga się jednak generalnie jakiejś takiej otoczki, że osoba kreatywna będzie też kreatywnie nawet wyglądać. Czasami spotkałam się, bo ja na przykład gdzieś tam jakoś nie uzewnętrzniam się, jeżeli chodzi o moją kreatywność, w stroju, ale też właśnie często widzę takie absurdy, że ludzie w agencjach po prostu są ubrani jak kolorowe ptaki, a nie są tak kreatywni. I to też jest jakaś pułapka [W19].

Widzimy więc, że od kreatywnego wymaga się niekonwencjonalnego stroju. Niektórzy badani jednak określają takie wybory modowe mianem

\footnotetext{
6 Był to jedyny wywiad przeprowadzony w parze, ponieważ badani pracują w jednym miejscu, dzieląc równocześnie życie prywatne.

7 Autorka wypowiedzi miała piercing widoczny na twarzy oraz inne charakterystyczne znaki szczególne, których nie mogę tu przywołać w trosce o prywatność badanej.
} 
„kreatywności na pokaz”. Część preferowała klasyczną elegancję, a inna grupa zupełnie nie przywiązywała wagi do wyglądu - wybierając wygodne T-shirty i zdając się na decyzje modowe partnerów życiowych. Takie osoby, stanowiące zdecydowaną mniejszość, trudno nazwać więc estetami pod względem ubioru. Czy można więc mówić o jakimkolwiek wzorcu? Z pewnością jest nim swoboda ubioru. W przeciwieństwie do swoich kolegów pracujących w obsłudze klienta, kreatywni mogli ubierać się tak, jak mieli na to ochotę.

Estetyzm można było zaobserwować w odpowiedzi na pytania o wystrój mieszkania. Kreatywni przywiązywali duże znaczenie do wyglądu samych pomieszczeń, jak i wyglądu przedmiotów codziennego użytku. Dla wielu ikoną był Philippe Starck, znany współczesny architekt i twórca wzornictwa, jako „ktoś, kto bierze normalny obiekt i robi z tego dzieło sztuki, które jest użytkowe" [W9]. W wystroju wnętrz dominował skandynawski minimalizm lub eklektyczne połączenia różnych elementów:

Znajomi mówią, że jak się wchodzi do mnie do mieszkania, ja wynajmuję już dziewiąte mieszkanie w Krakowie, więc każde, nawet jakby brzydkie nie było i tak dalej, to potrafię coś z nim tam zrobić. To jest dla mnie ważne, faktycznie nie potrafiłabym mieszkać w jakimś tam nie wiem, nieprzystosowanym do siebie otoczeniu, więc ja zawsze tak, na przykład znajomi mówią, po co ty wydajesz na to pieniądze, a ja właśnie lubię to [W8].

O tym, że postawa estetyczna, gust i dbałość o szczegół to cechy wyjątkowo pożądane w branży świadczą nie tylko dane z wywiadów. Można przekonać się o tym, analizując branżowe oferty pracy dostępne na portalach rekrutacyjnych lub w specjalnych grupach w mediach społecznościowych:

Sprawnie radzisz sobie z Photoshopem? Jesteś estetką, minimalistą, cenisz dobrą fotografię? Chcesz rozpocząć pracę w agencji reklamowej i rozwijać skill web designera/web designerki pod okiem wybitnych art directorów [źródło: Facebook, 29.01.2015, agencja VML].

Art Director. Trochę doświadczenia w agencji reklamowej. Duży talent i dobry gust. Wielka biegłość w programach PS, Ai, Id [źródło: Pracuj.pl, 22.01.2017, agencja Kropka Bordo].

Art Director. WYMAGANIA: m.in. 3 lata doświadczenia, wiedza z zakresu atl, digital, btl, zainteresowanie reklamą, zdolna rączka, kreatywność, bogate portfolio, samodzielność w organizacji pracy [źródło: Pracuj.pl, 10.03.2017, agencja Radna]. 
Senior Graphic Designer, Art Director. Czego wymagamy? Poczucia estetyki i precyzji oraz dbałości o szczegóły i detale. Doświadczenia w projektownaiu serwisów internetowych i identyfikacji wizualnej. Kreatywności, samodzielności, sumienności, znajmości trendów i skutecznych rozwiązań [źródło: migomedia.pl, 9.03.2017, agencja Migomedia, pisownia oryginalna].

Za umiejętnościami i wyczuciem (ucieleśniony kapitał kulturowy), dyplomami uczelni artystycznych (zinstytucjonalizowany kapitał kulturowy), posiadanymi przez wielu kreatywnych, oraz przedmiotami znajdującymi się w ich domach (zobiektywizowany kapitał kulturowy) szła wysoka samoocena gustu badanych. Można zaryzykować nazwanie tej postawy „wyższością estetyczną”. W wielu wywiadach powracało bowiem przeświadczenie, że kreatywni mają lepsze „poczucie estetyki” niż przeciętni odbiorcy reklam. Niektórzy pozwalali sobie na kpinę z osób niewyrobionych artystycznie, które nie dorównywały im poziomem kapitału kulturowego. Dobrą ilustracją jest fragment wypowiedzi jednego z dyrektorów kreatywnych, którzy zauważa, że ilustracje stanowią ważne elementy jego przestrzeni domowej. Tłumacząc, że nie są to zakupy „obrazów na ścianę”, lecz towarzyszy im zawsze pogłębiona refleksja, mówi, że zna osoby, które kupują obrazy, traktując je jak proste dekoracje. Przykładem takiej osoby jest jego sąsiad, prawnik. Choć jest to przypuszczalnie osoba o zbliżonym statusie społeczno-ekonomicznym, to różni ich kapitał kulturowy. Choć kreatywni nie używają oczywiście w swoich wypowiedziach tego terminu, dobrze opisuje on z perspektywy zewnętrznej różnicę pomiędzy pracownikami kreatywnymi i niekreatywnymi.

Estetyzm i swoboda wyboru w zakresie ubrania i wyposażenia mieszkania to tylko przykłady cech łączących kreatywnych. Choć wchodzą one w zakres etosu pracownika kreatywnego, nie wyczerpują wszystkich jego składowych, które wyróżniają twórców reklam spośród innych grup zawodowych. Pozostałe składowe to między innymi upodobanie swobodnej atmosfery w miejscu pracy, skłonność do posługiwania się profesjolektem, czy moda na nieoglądanie telewizji, które opisałem w innym miejscu [Łuczaj 2016]. Prezentacja codziennych wyborów estetycznych pracowników agencji reklamowych miała umiejscowić na właściwym tle problematykę, do której teraz przechodzimy - sposób, w jaki twórcy reklam starają się uwzględniać estetyczne potrzeby odbiorców reklam. 


\section{Relacja twórca - odbiorca w polu reklamy}

John Dewey zauważył, że jedną z czynności charakterystycznych dla artysty jest konieczność wyobrażenia sobie odbiorcy [Dewey 2004: 208] ${ }^{8}$. To, jak zdefiniujemy sobie sytuację rzutuje następnie bardzo silnie na symboliczne interakcje pomiędzy twórcą a odbiorcą. W jaki sposób radzą sobie z wyobrażaniem odbiorców kreatywni? O ich stosunku do źródeł wiedzy na temat konsumenta można, moim zdaniem, najlepiej opowiedzieć za pomocą metafory, nawiązującej do nazw trzech wielkich szkół w filozofii: pozytywistycznego empiryzmu, fenomenologii i egzystencjalizmu.

\section{Pozytywiści}

Zdaniem ojca pozytywizmu filozoficznego, Augusta Comte’a, badania społeczne (które on sam nazywa „fizyką społeczną") powinny opierać się na „całokształcie obserwacji bezpośrednich, właściwych jej, ale mających na względzie także konieczny związek wewnętrzny, wiążący ją z fizyką właściwą" [Comte 1977: 152]. Używane współcześnie pojęcie pozytywizmu ma jednak znacznie krótsze korzenie. W filozofii pogląd ten ugruntowali tzw. pozytywiści logiczni (R. Carnap, M. Schlick), a w socjologii głównie socjologowie amerykańscy (m.in. P. Lazarsfeld). W tym rozumieniu dobrze zrealizowane badania zawsze dostarczają ostatecznej, obiektywnej prawdy o świecie, która znajduje zastosowanie praktyczne.

W realiach agencyjnych najbardziej klarowne jest stanowisko „pozytywistów", którzy potrzebują twardych danych pochodzących z raportów i badań. Neopozytywistyczne kategorie mierzalności, pewności poznawczej i aplikowalności konstytuują typ legitymizacji rządzący niepodzielnie polem biznesowym. Agencyjni „pozytywiści” uważają, że pracę należy rozpocząć od briefu, czyli dokumentu kodyfikującego założenia kampanii, gdzie zwykle znajduje się opis grupy docelowej i inne kluczowe fakty [Kover 1995: 600]. Zwykle tzw. brief kliencki opracowywany jest dodatkowo przez dział strategii i przekształcany w brief kreatywny. Stratedzy opierają się na analizie danych rynkowych, branżowych raportach, a także śledzeniu trendów, które prowadzą na bieżąco. Jeden z pracowników kreatywnych określił pracę strategów jako „sprytną obserwację życia”, co, również w mojej

8 Wcześniejsza wersja zawartych w tej części artykuł analiz znajduje się w: [Łuczaj 2016]. 
opinii, dobrze oddaje jej charakter. Jako przykład typowego narzędzia strategów może posłużyć Target Group Index - olbrzymia, tworzona od 1969 roku, baza danych dotycząca upodobań konsumentów w różnych krajach świata, także w Polsce [Thornton 2003]. W epoce Big Data stratedzy sięgają po różne metody: bardzo skomplikowane modele matematyczne, lecz także ich przeciwieństwo określane jako Small Data, miękkie raporty firm badawczych specjalizujących się w etnografii [Lindstrom 2016].

Wykształcenie $\mathrm{z}$ zakresu nauk społecznych pomaga $\mathrm{w}$ realizacji zadań strategów. Z tego względu działy strategii bywają żartobliwie nazywane działami „psychologii i socjologii”. Brief kreatywny powinien zawierać tzw. insighty, czyli informacje o potrzebach konsumenta (jawnych lub ukrytych). Choć konflikty i spory kompetencyjne na linii strategia-kreacja nie są nieznane, to pozytywiści wysoko cenią pracę strategów:

Brief jest takim pierwszym elementem, żeby uświadomić klientowi co wie, czego nie wie, co ja bym chciał się dowiedzieć i też zwrócić mu uwagę, co moglibyśmy zrobić po to, żebyśmy znaleźli właśnie obszary, w których możemy popracować, głównie jeżeli chodzi o takie strategiczne rzeczy, bo nie sztuką jest tylko zlecić grafikę czy też zlecić kreację, jeżeli nie ma się po prostu wizji tego swojego pomysłu na biznes, na kampanie, na jakiekolwiek tego typu rzeczy [W5].

To jest wynik nie tego, że se koleś jeden z drugim siedli i pomyślał, a zrobimy taką kampanię, tylko wytężonej pracy całego zespołu, w tym duża część to jest strategia. Przecież większość z takich wielkich przetargów, jak są wielkie przetargi, to się nie wygra kreacją i jakimiś ładnymi obrazkami, to się wygrywa strategią [W9].

Logiczną konsekwencją rygorystycznie pojmowanego pozytywistycznego podejścia do reklamy byłoby znaczne ograniczenie możliwości decyzyjnych (a tym samym prestiżu) działu kreacji. W moich badaniach nie spotkałem się jednak z próbą tworzenia reklamy opartej wyłącznie na badaniach. Zagrożenie, które płynie z pozytywizmu, jest inne i można je określić jako „biurokratyzację pracy agencyjnej”. Podczas gdy praca w agencjach reklamowych jest przedstawiana w kulturze popularnej jako mocno nieustrukturyzowana ${ }^{9}$, nie jest to obraz prawdziwy. Dotyczy to szczególnie tych agencji, których struktura organizacyjna jest wyraźnie zarysowana. Badani opowiadali o procedurach akceptacji, których nie powstydziłaby się niejedna korporacja. W przypadku kampanii zdarza się, że projekt musi zostać opatrzony podpisami stratega, opiekuna klienta oraz dyrektora

9 Dobrymi przykładami mogą być amerykański serial Mad Men, francuski film 99 franków, czy książka Cięcia polskiego autora, Dawida Kornagi. 
kreatywnego, zanim trafi do zespołu, który będzie pracował nad szczegółami koncepcji.

Oczywiście reklamowy „pozytywizm” jest typem myślenia najbardziej odległym od wzorców znanych ze świata sztuki. O ile bowiem istnieją badania społeczne posługujące się sztuką, o tyle sytuacja odwrotna jest bardzo rzadka. Artyści zwykle preferują bardziej miękkie źródła inspiracji, podobnie jak agencyjni „fenomenologowie” i „egzystencjaliści”. Zdarzają się jednak sytuacje, w których badania i sztuka przeplatają się [PryszmontCiesielska 2015]. Projekty takie nie należą jednak do głównego nurtu badań społecznych, ani głównego nurtu sztuki. Jedynym głośniejszym przypadkiem wykorzystania metod socjologicznych do tworzenia sztuki był projekt People’s Choice realizowany przez w latach 1994-1997 [Wypijewski 1997]. Na podstawie profesjonalnego badania sondażowego skandalizujący artyści Vitaly Komar i Alexander Melamid malowali najbardziej i najmniej „pożądane" obrazy dla kilku wybranych krajów. Analiza danych statystycznych pozwoliła artystom dojść do wniosku, że na całym świecie, niezależnie od kraju i kultury, ludziom podobają się przedstawienia natury, a nielubiana jest sztuka abstrakcyjna. Z tym projektem wiążą się jednak dwie trudności. Pierwsza polega na tym, że trudno ocenić czy rezultaty projektu w postaci obrazów w ogóle stanowią sztukę. Po drugie, zwracano uwagę na fakt, że suma pojedynczych elementów wizualnych wskazanych przez respondentów wcale nie musi być tym, co rzeczywiście im się podoba. Projekt Komara i Melamida jest więc intelektualną prowokacją i choć znalazł uznanie, zastosowana metoda naukowa stanowi raczej wyjątek niż regułę w świecie sztuki.

Podsumowując ten wątek analizy, w pracy agencyjnej podparcie się autorytetem badań może przynieść dobry skutek, jednak problem polega na tym, że szczegółowe dane zwykle nie są dostępne zarówno dla twórców reklam, jak i artystów. W reklamie istnieje jednak większe zapotrzebowanie na twarde dane. Problem w tym, że często grupa docelowa nie jest precyzyjnie określona („najczęściej grupa docelowa to są everybody” [W17]). Dla „pozytywistów” jest to sytuacja kłopotliwa. Znacznie lepiej radzą sobie z nią "fenomenologowie” i „egzystencjaliści”, orientacje bardziej „miękkie”. Nie oznacza to jednak, że trafność ich przewidywań jest intuicyjna. Od lat czołowi konsultanci biznesowi opierający się na etnografii i badaniu „podtekstów kulturowych” (subtext research), [por. Lindstrom 2016] zdobywają uznanie w oczach czołowych marek, takich jak: Lego, Nestle czy Coca-Cola. Pokrewna propozycja - branding kulturowy Douglasa Holta [Holt, Cameron 2010] - sugeruje wprost, że bardziej miękkie, jakościowe badania 
pozwalają przełamać ortodoksję kulturową i stworzyć prawdziwie inspirującą reklamę

\section{Fenomenologowie}

Fenomenologia to nurt filozofii o przeszło stuletniej tradycji. Za jej ojca uważa się Edmunda Husserla, który na początku XX wieku szokował niemieckojęzyczny świat akademicki poglądem mówiącym, że wszelki początek w zdobywaniu poznania jest nienaukowy [Ingarden 1974: 77]. Naczelną zasadą fenomenologii jest „powrót do pierwotnego, bezpośredniego doświadczenia”. Choć pojawia się tu pojęcie „doświadczenia”, znane z prac pozytywistów, $w$ fenomenologii ma ono zupełnie inne znaczenie. Wybitny uczeń Husserla, Roman Ingarden, wyjaśnia że u fenomenologów istnieje wiele różnych rodzajów źródłowego doświadczenia, z których jednym jest intuicja [Ingarden 1974: 57-59]. Poznanie zmysłowe świata zewnętrznego to tylko jeden $\mathrm{z}$ rodzajów poznania; fenomenologowie, inaczej niż empirycznie zorientowani pozytywiści, nie negują możliwość wniknięcia w psychikę innej osoby. Ingarden zauważa, że zwykle potrafimy wczuć się w stany emocjonalne naszych bliskich: „często potrafię odkryć to, czego druga osoba nie może lub nie chce mi powiedzieć, ponieważ np. się wstydzi” [Ingarden 1974: 62]. Gdyby możliwość dotarcia do psychiki innej osoby nie istniała - kontynuuje Ingarden - „żylibyśmy obok siebie jak głusi i ślepi” [Ingarden 1974: 64]. Choć termin „wczucie”, w przeciwieństwie do „wglądu”, nie pochodzi $z$ tradycji fenomenologicznej ${ }^{10}, \mathrm{w}$ pewnym przybliżeniu pokazuje główną intuicję tej filozofii. Agencyjni fenomenologowie często starają się sobie wyobrazić publiczność reklamową, polegając przy tym przede wszystkim na wglądzie (tak przecież wypadałoby przetłumaczyć branżowy termin insight), intuicji i przeczuciu. Badania empiryczne mają dla nich drugorzędne znaczenie, ponieważ wglądy mogą - zgodnie z założeniami fenomenologii - je zakwestionować:

W ogóle uważam, że chyba najlepszym, takim możliwym testem dla reklamy jest moment też empatycznego spojrzenia, wczucie się w tego odbiorcę i zastanowienia się, patrzcie, jak on będzie na to patrzył [W3].

Intuicja. Intuicja, doświadczenie tylko w ten sposób, no i taki jakiś zdrowy rozsądek, OK, badania badaniami, ale też nie można wszystkiego kłaść na kartę, bo to jakiś, na zdrowy rozsądek, cel musi przyświecać temu [W11].

10 Na początku XX wieku kojarzono go głównie z - przeciwstawianym fenomenologii - psychologizmem. Obecnie jednak wczucie i wgląd są terminami o przybliżonym znaczeniu. 
No wiesz, grupa na przykład kobiet powyżej 50-60 lat, z żylakami, jest... my jesteśmy, się śmieję, ja myślę, że to jest wyobraźnia. Jak mówię, sky is the limit. Albo wchodzisz... to jest empatia, ja jednak pracuję bardzo intuicyjnie i empatycznie chyba, bo to jest tak, że nagle, jakby musisz wejść w ten świat właśnie chociażby takich kobiet, co jest ważne, jakiego rodzaju to jest emocjonalność na przykład [W17].

Myślę, że taka intuicja, która w tej branży jest dosyć ważnym elementem, no bo to nie jest ani wyuczone, to nie jest wyumiane, to jest gdzieś wyczytane, to jest gdzieś, to jest jakiś taki element człowieka, który jest związany z jego stylem, jego właśnie słuchaniem, obserwacją, albo też przekazywaniem swojej wiedzy [W5].

Mamy w agencji taką panią sprzątaczkę, która zawsze tam przed piątą wchodzi i staram się myśleć o tym, że to jest taka osoba, no nie, która ma pracę ciężką, ma do tego mnóstwo problemów na pewno, ona najczęściej kupuje rzeczy, które są jej absolutnie potrzebne, a nie, że ona szasta pieniędzmi na lewo i prawo, i wypróbowuje nowości, tylko do niej trzeba podejść z prostą historią, którą ona zrozumie, i z tej historii jakby wyniesie to przesłanie, które mówi o rzeczy, którą reklamuje, zrozumie, dlaczego powinna ją kupić, co jest w tej rzeczy dla niej atrakcyjne, pójdzie i to zrobi, no nie [W4].

Zacytowane wypowiedzi dobitnie pokazują, że zdaniem pracowników polskich agencji reklamowych, kluczowa części ich praca zależy od dobrego wyczucia i intuicji. Znamienne, że nawet autorka ostatniego cytatu, która mówi o życiu pani sprzątającej, nie podejmuje rozmowy z tą osobą, lecz stara się wczuć w to, co tamta myśli. Intuicja jest też typowym narzędziem artysty. „Fenomenologiczne” tworzenie sobie postaci odbiorcy bardzo przypomina tworzenie Czytelnika Modelowego, które opisał Umberto Eco, pisząc, że autor dzieła literackiego musi:

(...) założyć, że zbiór kompetencji, do którego się odwołuje, jest tym samym zbiorem, do którego odwołuje się jego czytelnik. Dlatego te będzie on przewidywał Czytelnika Modelowego zdolnego do współdziałania w aktualizacji tekstowej w taki sposób, w jaki on, autor, sobie to wyobrażał, i do dokonywania przy interpretowaniu takich posunięć, jakich autor dokonał przy generowaniu tekstu [Eco 1987: 294].

W tekście, którego fragment przytoczyłem Eco sam sugeruje analogię pomiędzy artystą a pracownikiem agencji reklamowej, wybierającym swój target. Tym, co ich łączy jest trudność dopasowania dzieła do kompetencji odbiory, ponieważ te nie dają się przewidzieć oraz zmieniają się w czasie. W obliczu tych faktów zarówno artyści, jak i twórcy reklam zdają się na swoją intuicję (i doświadczenie). Istnieje jednak jeszcze jedna możliwość wyobrażania sobie modelowego odbiorcy. 
W reklamie fenomenologiczne podejście do grupy docelowej może okazać się bardzo płodne, lecz wiąże się z nim również niebezpieczeństwo - publiczności mogą zostać wyobrażone w sposób schematyczny i uproszczony. Opieranie się na intuicji rodzi ryzyko, że w konstrukcję obrazu grupy docelowej wkradną się stereotypy, a te z kolei powodują, że o grupie docelowej zazwyczaj mówi się źle [W9].

Próba wczucia się w klienta ma jeszcze jedną wadę: kłóci się z ideologiami mierzalności, kalkulacyjności i przewidywalności obecnymi w polu biznesowym, które są, obok efektywności, również kluczowymi składowych Ritzerowskiego opisu „zmacdonaldyzowanego" społeczeństwa [Ritzer 2005]. Z tego względu konieczne jest maskowanie fenomenologicznych „wglądów”. Można je przeprowadzić za pomocą pozytywistycznej maszynerii w postaci statystyk:

Ale to nie wynikało z żadnych badań, tylko $\mathrm{z}$ Waszej intuicji?

Z naszej intuicji, tak. Znaczy wiesz, potem jakby Zośka, czyli strateg nasz, filtruje, jakby wiesz, to jest tak, że my nie mamy stricte, nie jesteśmy w stanie se pozwolić na robienie aż tak dogłębnych badań, ale na przykład już jesteś w stanie przedstawić wykresy, czego słucha grupa docelowa, jakie ogląda programy. No bo to już jakby $\mathrm{z}$ tych wszystkich dostępnych raportów strateg wyciąga, więc my jakby sprzedając coś takiego, jakby oczywiście bronimy to też cyframi, ale jakby czysto... prawda jest taka, że często te rzeczy powstają z głowy [W17].

Czasami jednak nie ma potrzeby maskowania fenomenologicznego podejścia do pracy, ponieważ jest ono spójne z różnymi branżowymi trendami, na przykład z popularną ostatnio metodologią design thinking, której założenia objaśnia jeden z badanych:

Design thinking jest to taka metoda budowania person, czyli nie robienia grup docelowych, tylko budowania kontekstu konkretnej postaci, która jest reprezentantem takiej grupy docelowej, i to jest takie ćwiczenie, które pozwala uzmysłowić psychologicznie, jak wygląda takowa, taki reprezentant grupy i osobom będącym po drugiej stronie lustra, czyli tym, którzy będą do niej coś kierowali (...), wiadomo, że trafność jest znowu intuicyjna, ale jak gdyby jest to bliższe, niżby zlecać badania [W5].

Autor tej wypowiedzi tłumaczy następnie, że design thinking przewyższa tradycyjne podejście marketingowe, ponieważ porzuca się tu myślenie w kategoriach bliżej nieokreślonej grupy, na rzecz myślenia w kategoriach doświadczenia użytkownika. W tym sensie design thinking zbliża się więc do modelowego „egzystencjalizmu”, tak jak filozoficzny egzystencjalizm jest kierunkiem pokrewnym fenomenologii. 
Postawy, które nazywam fenomenologicznymi pojawiały się oczywiście także w zachodnich badaniach dotyczących agencji reklamowych. Badacze kreatywności, tacy jak Stephanie O’Donohoe i współpracownicy [2008: 517] oraz John Sellers [1999: 61] zauważają, że dyrektor artystyczny intuicyjnie rozumie, co zrobić z informacjami na temat projektu, które dostaje od współpracowników. Częściowo intuicje te nabywane są w procesie enkulturacji, kiedy nowa osoba uczy się zwyczajów panujących w branży, stając się członkiem społeczności praktyk [Grabher 2004: 254]. „Fenomenologia” jest zgodna $\mathrm{z}$ powszechną w branży niechęcią do badań, która pojawiała się zarówno w moich badaniach, jak i źródłach dotyczących pracy w przemysłach reklamowych innych krajów [zob. np. Sullivan 2007]. Nastawienie fenomenologiczne może być bardzo efektywne, o czym przekonują sukcesy Steve'a Jobsa i kierowanej przez niego firmy Apple. Moi rozmówcy wskazywali również przykłady takich sytuacji, w których zlecenie badania nie jest konieczne, ponieważ to, czy odbiorca będzie w stanie zdekodować przekaz reklamowy, wynika z ogólnych doświadczeń pokoleniowych i wydarzeń medialnych, z którymi stykają się użytkownicy określonych mediów. Również praktycy badań marketingowych zauważają, że w niektórych przypadkach potwierdzają one to, co wiemy już intuicyjnie [Izmałkowa 2012].

\section{Egzystencjaliści}

Ostatnią metodę, która służyła kreatywnym do poznawania potrzeb odbiorców reklam można nazwać „egzystencjalną”. Jej głównym celem była chęć poznania życia takim, jakie ono jest, nawet jeżeli obserwacje prowadzące do sformułowania tego obrazu nie byłyby systematyczne. „Egzystencjalizm” w reklamie jest podobny do „fenomenologii”, jednak prowadzenie obserwacji empirycznych różni go od tej postawy. Nie muszą to być jednak obserwacje systematyczne. W tym sensie „egzystencjalizm” jest postawą, którą należy umieścić pomiędzy oboma opisanymi dotąd orientacjami teoretycznymi.

Z perspektywy historyka filozofii, egzystencjalizm to prąd, który częściowo wywodzi się z fenomenologii, dlatego nie sposób jednoznacznie oddzielić ich od siebie. Egzystencjalizm to filozofia uprawiana zawsze z punktu widzenia konkretnej jednostki, dlatego że wskazuje na „niemożność wyjścia poza ludzką subiektywność" [Sartre 1998: 29]. Jean-Paul Sartre pisał wprost, że w optyce egzystencjalnej „nie istnieje determinizm, człowiek jest wolny, człowiek jest wolnością” [Sartre 1998: 38], dlatego też „nie ma innej rzeczywistości, jak tylko działanie” [Sartre 1998: 52]. Kluczowe znaczenie dla egzystencjalistów ma doświadczenie ludzkie („egzystencja”), 
które jest bardziej pierwotne niż istota („esencja”). W jaki sposób ten pogląd można odnieść do praktyki wytwarzania komunikatów reklamowych?

Dobrze widać to na przykładzie podręczników dla przyszłych designerów. Jeden $\mathrm{z}$ nich zawiera taką oto wskazówkę: „być może najważniejsze jest rozmawiać z ludźmi. Dzielić się pomysłami, słuchać, jakiego języka używają, przykładać wagę do tego, co ich inspiruje i uczyć się od innych, gdy dzielimy się z nimi naszymi spostrzeżeniami” [Dabner, Calvert i Casey 2010: 11].

Jest to wezwanie do konfrontowania swoich pomysłów („wglądów”) z pomysłami innych osób. Podejście to zostało głęboko zinternalizowane przez polskich twórców reklamy. Najpopularniejszą praktyką „egzystencjalistów” było poszukiwanie w swoim otoczeniu osób podobnych do adresatów kampanii. Mogli to być znajomi, rodzice lub inni członkowie rodziny lub osoby spotkane zupełnie przypadkowo:

Natomiast, no, jak nie [ma badań - K.Ł.], no to kombinujesz. Pytasz się, sprawdzasz, wiesz, dzwonisz po znajomych, co robili tam, a co twój syn robił? No bo sami sobie nie wymyślimy [W13].

Oprócz tego, staram się obserwować na przykład swoich rodziców i szukam osób, które faktycznie są w tym wieku i staram się z nimi przynajmniej porozmawiać, albo dowiedzieć się, jak one funkcjonują i jak żyją [W15].

A jak to jest grupa, o której ma Pani małe pojęcie.

Czyli jaka?

Robotnicy budowlani na przykład.

Mam pojęcie o robotnikach.

A skąd Pani czerpie te wiadomości?

Nie wiem, z remontów, które w życiu robiłam, firmy budowlanej [którą dobrze znam], od tych gości, którzy się wszyscy przewijali. (...) Jak mieliśmy [działania] do nastolatków kierowane, to siedzieliśmy na chatach i dzwoniliśmy po ludziach, którzy znają jakieś dzieci [W9].

R21: Nie żyjemy w bańce, więc mamy kontakt z różnymi ludźmi, czy w czasie wakacji, czy w czasie podróży, więc tak naprawdę mamy dostęp praktycznie do każdej grupy docelowej.

R22: Ale poza tym, przy niektórych produktach też, nie wiem, jakieś fora internetowe, jakieś portale, na które wchodzą te osoby [W21].

Ja bym się na przykład babci spytała, co by chciała dostać pod choinkę, bo muszę przyszykować jakiś prezent, bo akurat takie mam zadanie. No to tak jakby się po prostu bezpośrednio pyta, gdzieś tam wśród bliskich lub znajomych, podpatruje 
się ich. No bo wiadomo, że ludzie są najlepszym źródłem dla nas, więc trzeba ich obserwować [W19].

Wypowiedzi te wskazują, że pracownicy polskich agencji reklamowych, na podstawie ulotnych kontaktów z osobami ze swojego otoczenia, budują obraz pewnych grup i kategorii społecznych. Często jest to bardzo opłacalna strategia, ponieważ $w$ nieformalnych rozmowach można dotrzeć do potrzeb odbiorcy lub negatywnie zweryfikować swój wstępny pomysł. Nie zawsze potrzebne są badania reprezentatywne. Jak zaznaczyłem wcześniej, również artyści rzadko sięgają po badania ilościowe, poprzestając na obserwacji świata wokół nich lub rozmowach z osobami z interesujących ich środowisk ${ }^{11}$. W literaturze doświadczenie biograficzne może rzutować na przedstawione wydarzenia lub język bohaterów (co widać np. w prozie Doroty Masłowskiej). Często nie jest to materiał zbierany celowo, co nie przekreśla faktu, że można go wykorzystać w dziele.

Inna odmiana „egzystencjalizmu” polegała na zbieraniu informacji nie bezpośrednio od ludzi, lecz ze źródeł pisanych, takich jak reportaże prasowe, książki lub inne teksty kultury. Często inspiracją są też kampanie zagraniczne. Jedna $z$ badanych, pracująca w mniejszej agencji, opisuje powtarzający się w różnych wywiadach, sposób gromadzenia informacji przez kreatywnych:

Zaczynamy, dowiadujemy się jaki mamy produkt. Potem przeszukujemy, jak ten produkt jest reklamowany na świecie, w Europie, jeżeli nic nie znajdujemy, przeważnie coś tam się znajdzie, tu jedziemy, jest taki sklepik z takimi książkami zza granicy, oni sprowadzają właśnie o designie, o najnowszych trendach, kupujemy kilka książek i to jest tak, że po prostu się siedzi, wertuje, to ogląda i głowa mieli [W6].

W bardzo podobny sposób na temat źródeł swoich inspiracji wypowiadają się niektórzy artyści. Za przykład przytoczmy słowa Sabiny Twardowskiej z początku 2017 roku:

Nie dzieje się nic to wystawa prac, które powstały w wyniku uważnej obserwacji otaczającej mnie rzeczywistości. Na zawartość tych obrazów składają się treści absurdalne i mocno populistyczne - płynące z telewizji, prasy, polityki i portali społecznościowych. Mam wrażenie, że doświadczamy obecnie ciężkiej kakofonii

11 Powstanie serii fotografii Romana Ondaka Casting Anitnomads (2000, Pomeranz Collection, Wiedeń) poprzedziło badanie ankietowe na małej próbie członków rodziny, przyjaciół i znajomych, którego celem było wychwycenie osób niepodróżujących, które lubią pozostawać w domu. 
informacyjnej, co powoduje zacieranie granic pomiędzy tym, co istotne, rzeczywiste, bzdurne i niebezpieczne. Swoimi obrazami oswajam tę dziwną rzeczywistość; wprowadzam humor, który pomaga mi zachować dystans do spraw, które wzbudzają mój niepokój ${ }^{12}$.

\section{Łączenie orientacji i przeplatanie się obowiązków}

Jedna z autorek przytoczonych powyżej cytatów zaznaczyła, że raport na temat odbiorców to głównie zadanie strategii, a kreacja może z niego korzystać. W tym sensie łączyła ona orientację egzystencjalną (typową dla kreatywnych) i pozytywistyczną (typową dla strategów ${ }^{13}$ ). Nie była to jednak reguła. Niektórzy kreatywni lubią samodzielnie poszukiwać informacji na temat odbiorców („Ja chyba nawet wolę, szczerze mówiąc, sama, bo wtedy, jak się sprawdza wszystko po kolei, to więcej wiem" [W15]). W życiu agencyjnym bardzo często zdarza się jednak, że pracownicy wykonują zadania przypisane do innych stanowisk. Bardzo rzadko obowiązuje ścisły podział. Nawet copywriterzy, odpowiedzialni zasadniczo za tekst, włączają się w prace dyrektorów artystycznych i grafików, a ci komentują reklamowy copy (tekst). Z tego względu, jak tłumaczyli badani, najlepsze pomysły powstają w różnych okolicznościach. Niekoniecznie podczas wytężonej pracy nad briefem:

Wiesz, wychodzi się na papierosa, od słowa do słowa, ktoś coś powie, odbija się to od drugiego człowieka i to najczęściej nie jest tak, że my teraz bardzo mocno kminimy nad briefem, tylko najczęściej to są jakieś dygresje dookoła, oczywiście około tematu i wtedy to się rodzi. Więc tak to wygląda. I dopiero później jakby następuje selekcja, bo to jest też ważne, że ten pomysł, jak jest płodna agencja, tych pomysłów jest dużo i potem jakby musi nastąpić twarda selekcja, z czym idziemy [W17].

Ten rodzaj kreatywności przypomina dokonaną przez Randalla Collinsa [2011] analizę rytuałów tytoniowych. Jeden z najważniejszych rodzajów rytuału tytoniowego wiąże się z uwolnieniem od presji oraz nerwami związanymi z pracą i relacjami społecznymi [Collins 2011: 347]. Rytuały tytoniowe dokonywały się często $\mathrm{w}$ przerwach $\mathrm{w}$ pracy. Collins zauważa jednak, że tytoń, podobnie jak kawa, kojarzony jest również z ożywieniem $\mathrm{i}$ ta jego cecha jest bardziej istotna w przypadku agencji reklamowych.

12 Źródło: http://bwa.esanok.pl/k/aktualnosci, [19.03.2017].

13 Ściślej - typową dla wizerunku strategów z perspektywy pracowników kreatywnych. 
Palenie pozwala bowiem mieć uczucie przynależności do zamkniętej grupy, bycia „w centrum akcji” [Collins 2011:358]. Collins przypomina, że chętnie stosowali go w trakcie spotkań dziennikarze, ludzie teatru i inni intelektualiści. Moja analiza wskazuje, że jest on niezwykle popularny również w agencjach reklamowych, gdzie palenie to część procesu kreatywnego [Collins 2011: 357]. Rytuał tytoniowy pozwala poczuć specyficzną atmosferę, którą możemy określić jako „aurę kreatywności”. To właśnie dzięki niej dobre pomysły powstają często w „przerwach na papierosa”.

\section{Podsumowanie}

W artykule omówiona została rola wartości estetycznych, którymi kierują się w życiu codziennym kreatywni twórcy reklam, a także sposoby wyobrażania przez nich publiczności. W pierwszej kwestii należy przede wszystkim podkreślić estetyzm badanych, wyrażający się głównie w ich dbałości o ubiór i wystrój mieszkania (modne dodatki, minimalizm, eklektyzm). Naczelną zasadą, która rządziła ich gustem, była jednak swoboda - możliwość dowolnego łączenia elementów, zgodnie z odczuwanymi w danej chwili potrzebami. Owa nieskrępowana kreatywność, zdolność wytwarzania nowych idei i powiązana z nią zdolność wyczucia kontekstu, jak się okazało, była również jedną z najważniejszych cech udanych reklam, które wskazywali uczestnicy mojego badania [por. Łuczaj 2017]. Z ciągłą dbałością o szczegóły i estetykę w życiu codziennym wiązały się jednak pułapki, takie jak - omówione wcześniej - „kreatywność na pokaz” czy ryzyko wystąpienia „wyższości artystycznej”.

W odniesieniu do drugiego problemu badawczego zaproponowałem metaforę trzech szkół filozoficznych: pozytywizmu, fenomenologii i egzystencjalizmu. Ich podstawowe charakterystyki pozwalają obrazowo przedstawić trzy różne sposoby docierania do potrzeb odbiorców, choć należy pamiętać, że jest to tylko metafora i wielu historyków filozofii mogłoby pokazać jej niedoskonałości. „Pozytywiści”, współpracując ściśle z działami strategii, są skłonni opierać się na badaniach i analizach rynkowych. W ten sposób oddają część swojej anatomii na rzecz innych pracowników agencji. „Fenomenologów” i „egzystencjalistów” łączy skłonność do posługiwania się intuicją. Autonomia twórcy jest dla nich bardzo istotna. Różni ich stosunek do polegania wyłącznie na własnym osądzie i guście estetycznym drudzy, w przeciwieństwie do pierwszych, byli skłonni obserwować ludzi w nieustrukturyzowany sposób i wyciągać kluczowe wnioski z tych (przypadkowych, można by dodać) obserwacji. „Fenomenologowie” pozostawali 
przy wglądach i intuicji. „Pozytywizm”, „fenomenologia” i „egzystencjalizm” to trzy zupełnie inne sposoby opracowywania komunikacji marketingowej i nie można stwierdzić, że któryś z nich jest lepszy niż inne, choć można zauważyć, że praca w dużej, ustrukturyzowanej agencji (a więc możliwość korzystania z bogatych zasobów ludzkich), wzmaga pokusę zostania „pozytywistą".

Sukces w świecie reklamy polega w dużej mierze na elastyczności umiejętności dostosowania się do oczekiwań zleceniodawców, odbiorców i kolegów z zespołu. Siłą rzeczy nieunikniony jest zazwyczaj kompromis, nawet gdy niektórzy twórcy chcieliby go nazwać zgniłym. Współistnienie tych trzech sposobów podejścia do wymagań odbiorcy pokazuje, że reklama jest przemysłem specyficznym, gdzie na wyłączność nie może liczyć ani myślenie technokratyczno-racjonalne (charakterystyczne dla biznesu), ani czysto artystyczne (charakterystyczne dla świata sztuki). Z tego względu Charles Wright Mills [1963: 374] mógł stwierdzić, że projektant to osoba, która znajduje się pośrodku (man in the middle), ponieważ „ich sztuką jest biznes, a ich biznesem sztuka”.

\section{Bibliografia}

Becker H. (1982), Art Worlds, Berkeley, Los Angeles, Londyn.

Bourdieu P. (1993), The Field of Cultural Production: essays on art and literature, Nowy Jork.

Bourdieu P. (2005), Dystynkcja. Społeczna krytyka władzy sadzenia, Warszawa.

Bourdieu P., Passeron J.-C. (1979), The Inheritors, Chicago, Londyn.

Collins R. (2011), Łańcuchy rytuałów interakcyjnych, Kraków.

Comte A. (1977), Czym jest filozofia pozytywna?, [w:] B. Skarga, Comte, Warszawa, s. $149-153$.

Dabner D., Calvert S., Anoki C. (2010), Graphic Design School. The Prinicples and Practice of Graphic Design, Hoboken.

Eco U. (1987), Czytelnik modelowy, „Pamiętnik Literacki”, nr 2, s. 287-305.

Florida R. (2010), Narodziny klasy kreatywnej, Warszawa.

Golka M. (1994), Świat reklamy, Puszczykowo.

Gołaszewska M. (1970), Świadomość piękna. Problem genezy, funkcji, struktury i wartości w estetyce, Warszawa.

Gołaszewska M. (1977), Zarys estetyki, Kraków.

Gołaszewska M. (1984), Estetyka i antyestetyka, Warszawa. 
Gronow J. (2001), The Sociology of Taste, Londyn, Nowy Jork.

Holt D., Cameron D. (2010), Cultural .Strategy: Using Innovative Ideologies to Build Breakthrough Brands, Oxford

Horowitz T. (1975), The Man in the Middle, "Journal of Market Research Society", nr 17, s. $26-40$.

Ingarden R. (1974), Wstęp do fenomenologii Husserla, Warszawa.

Kaufmann J.-C. (2004), Ego. Socjologia jednostki. Inna wizja człowieka i konstrukcji podmiotu, Warszawa.

Kover A. (1995), Copywriter's Implicit Theories of Communication: An Exploration, "Journal of Consumer Research", nr 21, s. 596-611.

Mills C.W. (1963), The Man in the Middle: The Designer, [w:] idem, Power, Politics and People, Oxford, s. 374-386.

Lahire B. (2006), La Condition littéraire. La double vie des écrivains, Paryż.

Lindstrom M. (2016), Small Data -The Tiny Clues That Uncover Huge Trends, Nowy Jork.

Łuczaj K. (2016), Współczesna polska reklama prasowa: co mówia reklamy, ich twórcy i odbiorcy, Kraków.

Łuczaj K. (2017), Dobra komunikacja marketingowa w oczach pracowników polskich agencji reklamowych, „Marketing i Rynek”, nr 6, s. 27-37.

Ostrowicki M. (1996), Teoria sytuacji estetycznej M. Gołaszewskiej jako fundament estetyki, „Edukacja Filozoficzna”, nr 22, http://www.sideymyoo.art.pl/Teoria_sytuacji_estetycznej.pdf, [30.09.2018].

Pryszmont-Ciesielska M. (2015), Między performansem a działaniem. O pewnym wariancie badań posługujących się sztuka (na marginesie projektu poświęconego matkom wykluczonym), „Teraźniejszość - Człowiek - Edukacja”, nr 2, s. 97-105.

Ritzer G. (2005), Makdonaldyzacja społeczeństwa, Warszawa.

Sartre J.-P. (1998), Egzystencjalizm jest humanizmem, Warszawa.

Sennett R. (2008), The Craftsman, New Haven.

Sosnowski L. (1999), Roman Ingarden wobec sztuki multimedilanej, [w:] K. Wilkowszewska (red.), Piękno w sieci. Estetyka a nowe media, Kraków, s. 103-108.

Sullivan L. (2007), Spoty, plakaty i slogany, Gliwice.

Szlendak T. (2011), Nic? Aktywność kulturalna na wsi i w małych miastach, [w:] I. BukrabaRylska, W.J. Burszta (red.), Stan i zróżnicowanie kultury wsi i małych miast w Polsce, Warszawa, s. 53-101.

Warczok T. (2013), Iluzja „ja”. W stronę relacyjnego widzenia podmiotu działającego, „Annales Universitas Paedagogicae Cracoviensis Studia Sociologica”, t. 5, s. 29-41.

Wypijewski J. (1997), Painting by Numbers. Komar and Melamid's Scientific Guide to Art, Nowy Jork.

Thornton S. (2003), An academic Alice in Adland: Ethnography and the commercial world, “Critical Quarterly", nr 41(1), s. 58-68.

Tracewicz J. (2017), Młodzi ludzie renesansu, „Polityka”, nr 3097, s. 84-85. 


\section{SUMMARY}

\section{Aesthetic Situation in the World of Advertising Agencies. How Can Sociology of Advertising Benefit from the Aesthetics and Sociology of Art?}

The products of creative industries in many aspects resemble works of art- the similarities lay both in the production process based on creative skills (going beyond techne), and the decoding process (requiring symbolic skills from the recipient). Taking advantage of aesthetic theories may be a remedy for the deficiency of theoretical works devoted to advertising. The article discusses the results of a research on Polish advertising agencies, based on the conceptual apparatus taken from classical aesthetics (R. Ingarden, M. Gołaszewska), as well as Pierre Bourdieu's sociology of art. It is aimed at answering two research questions: what aesthetic values are fundamental to the work of advertising creative staff, and how they try to comprehend the needs of recipients.

Keywords: advertising agencies, advertising in Poland, aesthetics in advertising, aesthetic situation 